\title{
Dental Gold Alloys
}

\section{COMPOSITION, PROPERTIES AND APPLICATIONS}

\author{
Helmut Knosp, Mirza Nawaz and Manfred Stümke \\ Degussa-Pforzheim, Pforzheim, Federal Republic of Germany
}

\section{The special qualities called for in materials for restorative and corrective dental devices have led to the development of a wide variety of dental alloys. Gold alloys, ranging from simple to very complex, are available which satisfy the technical and aesthetic needs of both practitioners and technicians.}

The long and fascinating story of the use of gold in dentistry has been recorded in this journal by Donaldson (1). The early dental applications of the metal, dating back to 2500 B.C., involved mainly the binding of artificial teeth to existing teeth (Figure 1). Apparently, the void caused by the loss of a tooth was more a problem of vanity than of inability to chew (2). The art of making fixed bridges from gold wire or strip was highly developed among the Etruscans and extensively practised by the Romans, but was lost in the Middle Ages. Only as late as the middle of the nineteenth century was the technique re-discovered and used again.

It was the application of the age-old practice of investment casting, around the turn of this century, which paved the way for the modern applications of gold in dentistry. These now consume a significant proportion of world gold production. Thus, in 1979 the Western World used 87 tons of gold for dental purposes. This amounted to 6.6 per cent of the total tonnage of gold consumed in fabricated form in that year (3).

With the introduction of the investment casting technique, gold alloys containing silver and copper became standard dental materials. Also, as early as 1905, hardenable gold-platinum alloys were developed in the U.S.A. because platinum was then very much cheaper than gold. One such alloy contained 12.5 per cent platinum in addition to 62.5 per cent gold. However, with the increasing price of platinum, alloys of this type became less important.

Fig. 1 A copy of the 'Gaillardot find'. The original item consisting of a portion of the jaw, two canines, two incisors and two substitute partial incisors, apparently deriving from another individual and bound in place with gold wire, was found in $\mathbf{1 8 6 4}$ by Gaillardol in a Phoenician buritl site dating from the fourth century B.C., in Sidon (now Saida) in southern Lehanon
In the 1920's, dental alloys containing little or no gold at all became available. Some of the white precious metal alloys developed during that decade contained less than 10 per cent gold and consisted mainly of silver and palladium. In the 1930's, pale yellow alloys containing 50 per cent gold were introduced. Both these groups of alloys are still on the market.

The development of the gold-rich dental casting alloys which are most widely used today began towards the end of the 1940's. They can now be considered as fully evolved and are the only group of dental gold casting alloys for which specifications are available (4), (see also Table II).

In many applications, however, alloys used for porcelain veneering are playing an increasingly important role. The technique of porcelain veneering began with Pierre Fauchard (1678-1761) who had gold denture bases enanelled red to imitate the gums. In 1808, Giuseppangelo Fonzi published a method for making porcelain teeth with fused-in platinum hooks. An important contribution was also made in this area by Charles Henry Land (1847-1919) who fused porcelain on thin platinum caps for use as

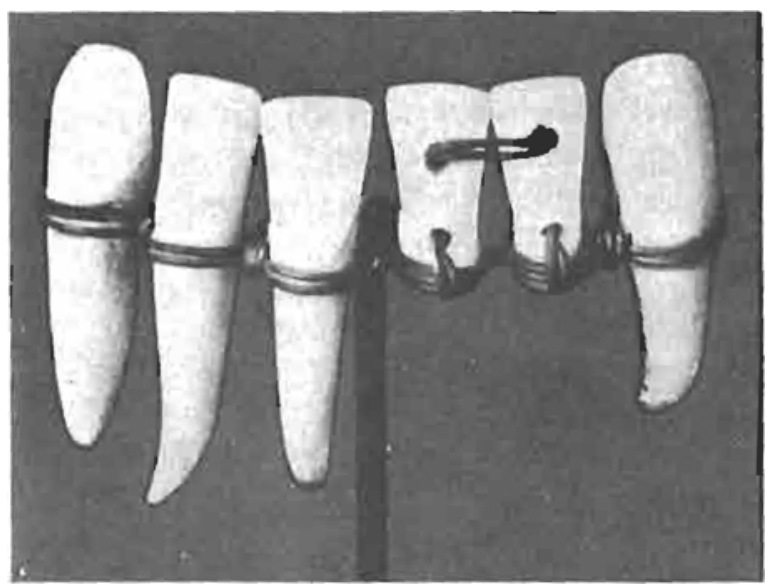


Table I

Compositions and Applications of the Main Groups of Dental Gold Alloys

\begin{tabular}{|c|c|c|c|c|}
\hline \multirow{2}{*}{$\begin{array}{l}\text { Alloy } \\
\text { group }\end{array}$} & \multicolumn{2}{|c|}{$\begin{array}{c}\text { Noble metals contents, } \\
\text { wt. \% }\end{array}$} & \multirow{2}{*}{$\begin{array}{c}\text { Main } \\
\text { constituents }\end{array}$} & \multirow[t]{2}{*}{ Applications* } \\
\hline & $\mathrm{Au}$ & PGM & & \\
\hline gold-silver(-copper) & $>80$ & & $\begin{array}{l}\mathrm{Au}, \mathrm{Ag} \\
\mathrm{Au}, \mathrm{Ag}, \mathrm{Cu}\end{array}$ & $\begin{array}{l}\mathrm{C} \\
\mathrm{C}\end{array}$ \\
\hline gold(-silver)(-copper)-PGM's & $\begin{array}{l}>85 \\
>75 \\
>70 \\
>65 \\
>60\end{array}$ & $\begin{array}{l}>10 \\
<10 \\
<15 \\
<15 \\
<40\end{array}$ & $\begin{array}{l}\mathrm{Au}, \mathrm{Pt} \\
\mathrm{Au}, \mathrm{Pt}, \mathrm{Pd} \\
\mathrm{Au}, \mathrm{Ag}, \mathrm{Pt}, \mathrm{Pd} \\
\mathrm{Au}, \mathrm{Ag}, \mathrm{Cu}, \mathrm{Pt}, \mathrm{Pd} \\
\mathrm{Au}, \mathrm{Pt}, \mathrm{Pd}\end{array}$ & $\begin{array}{l}\text { P } \\
P \\
A, C, S \\
A, C, S, W \\
A, R\end{array}$ \\
\hline gold(-silver)(-copper)-palladium & $\begin{array}{l}<60 \\
<60 \\
>40 \\
>40\end{array}$ & $\begin{array}{l}<10 \\
<10 \\
>30 \\
>30\end{array}$ & $\begin{array}{l}\mathrm{Au}, \mathrm{Ag}, \mathrm{Pd} \\
\mathrm{Au}, \mathrm{Ag}, \mathrm{Cu}, \mathrm{Pd} \\
\mathrm{Au}, \mathrm{Pd} \\
\mathrm{Au}, \mathrm{Ag}, \mathrm{Pd}\end{array}$ & $\begin{array}{l}\text { C } \\
\text { C, S } \\
\text { P } \\
P\end{array}$ \\
\hline (gold)-silver(-copper)-palladium & $\begin{array}{l}<30 \\
<10 \\
<10 \\
<10 \\
<10\end{array}$ & $\begin{array}{l}<15 \\
<30 \\
<40 \\
<50 \\
<60\end{array}$ & $\begin{array}{l}\mathrm{Au}, \mathrm{Ag}, \mathrm{Cu}, \mathrm{Pd} \\
\mathrm{Ag}, \mathrm{Pd}, \mathrm{Cu} \\
\mathrm{Ag}, \mathrm{Pd}, \mathrm{Cu} \\
\mathrm{Ag}, \mathrm{Pd}, \mathrm{Cu} \\
\mathrm{Ag}, \mathrm{Pd}\end{array}$ & $\begin{array}{l}\text { S } \\
\text { C } \\
\text { A, R } \\
0 \\
P\end{array}$ \\
\hline gold-nickel & $>80$ & & $\mathrm{Au}, \mathrm{Ni}, \mathrm{Zn}$ & $\mathrm{S}$ \\
\hline
\end{tabular}

$\mathrm{A}=$ attachments, $\mathrm{C}=$ castings, $\mathrm{O}=$ orthodontic wire, $\mathrm{P}=$ porcelain veneering, $\mathrm{R}=$ root canal posts, $\mathrm{S}=$ solders, $\mathrm{W}=$ clasp wire

crowns. This techique is still used in making jacket crowns. The importance of the choice of suitable alloys for porcelain veneering was recognized when attempts were made in the early 1930's to fuse porcelain to the frames of bridges made of platinumiridium alloy. The poor workability of this high melting range alloy and the incompatibility of its properties with those of dental porcelains very often led to failures. The alloys currently used in porcelainfused-to-metal techniques contain 70 to 90 per cent gold and their development began in the 1950's. They have now reached an advanced degree of sophistication (5).

\section{Dental Gold Alloys}

Before discussing the current use of gold alloys in dentistry, it is appropriate to review very briefly the metallurgy and properties of the three main families of such alloys that are available commercially to practitioners and technicians.

\section{Gold-Silver-Copper Alloys}

The metallurgy of gold-silver-copper ternary alloys is well known because of their extensive use in jewellery manufacture. Most of the dental alloys of this type (Table I) are hardened either by slow cooling after casting or by ageing at $400^{\circ} \mathrm{C}$. Hardening is due to the precipitation of copper-rich and silver-rich phases, as well as to the order-disorder transformations in the gold-copper system. The simultaneous occurrence of both these processes is responsible for the strong hardenability of these alloys $(6,7)$. During the ageing treatment, holding at low temperatures for a long time results in continuous phase precipitation, whereas after holding at high temperatures discontinuous lamellae are observed (8). The ultimate degree of hardening of these alloys is largely dependent on the amount of copper present, which is usually between 1 and 10 per cent.

\section{Gold-Silver-Copper-PGM Alloys}

Dental alloys of this kind (Table I) are most commonly used. The platinum group metals (PGM's) platinum and palladium, particularly the former, improve several properties of gold alloys. They cause grain refining, which is of great importance for casting alloys since it makes their structure less sensitive to overheating of the melt. Furthermore, the addition of PGM's enhances the tarnish and corrosion resistance of gold-based alloys in the oral environment. Additions of platinum also increase the hardness. This is probably an effect of the miscibility gap in the gold-platinum system $(9,10)$. Platinumcontaining alloys are usually based on compositions with more than 65 per cent gold by weight, while those with palladium additions contain less gold. 

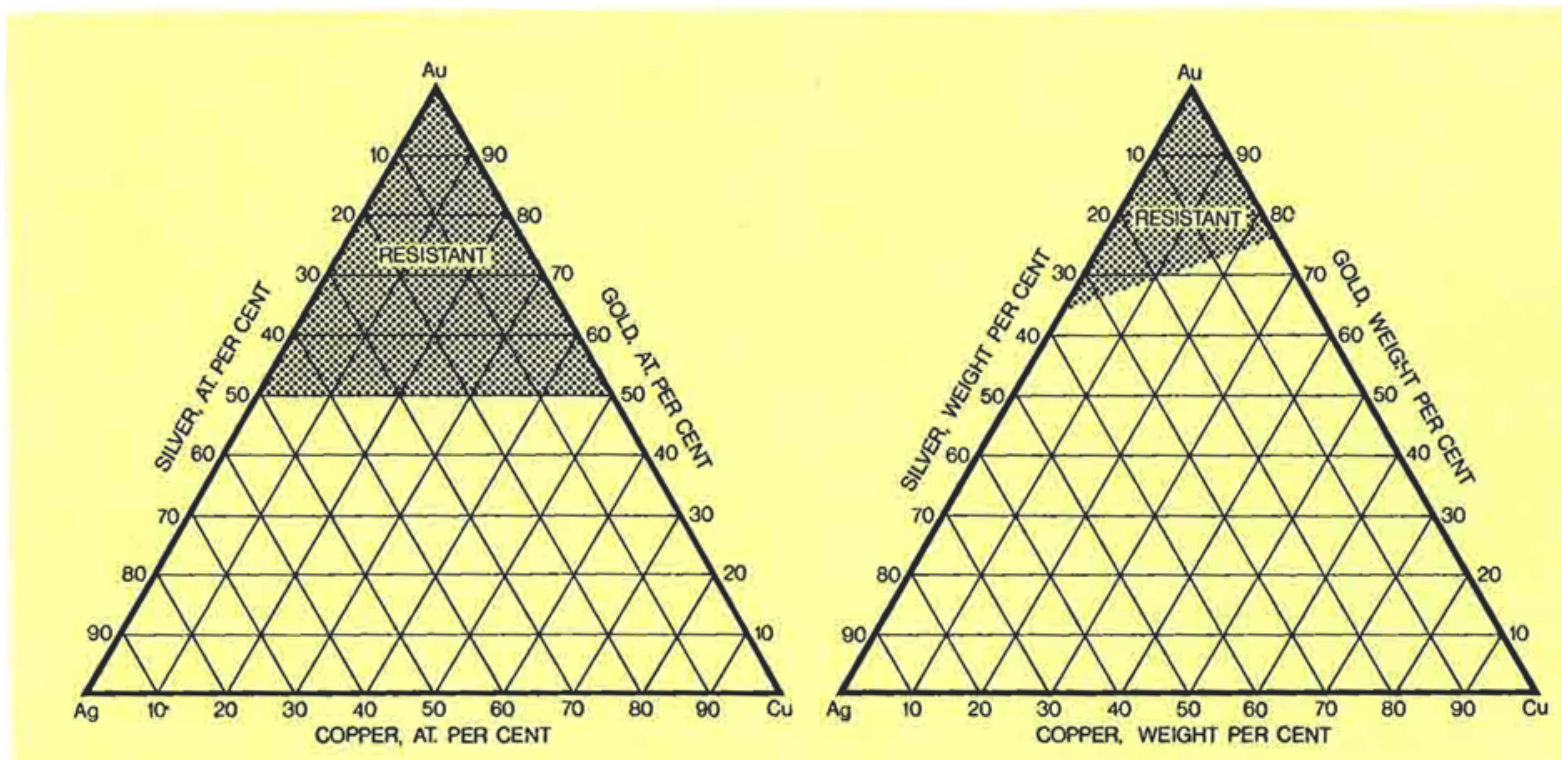

Fig. 2 The range of compositions of gold-silver-copper alloys which are resistant to attack by nitric acid, shown on the ternary diagram. After Tanmann (13)

These low gold alloys, when they do not contain copper, commonly contain indium or tin and harden by precipitation processes which take place in the goldpalladium-indium or gold-palladium-tin systems.

Dental gold alloys containing both platinum and palladium and no silver or copper have also been developed. X-ray studies have shown that these alloys harden as a result of the gold-platinum spinodal decomposition (10). Additions of indium and of tin further increase their hardenability and assist in lowering their otherwise high melting range.

\section{Silver-Copper-Palladium Alloys}

These alloys (Table I) contain very little or no gold. Hardening in them reflects the limited mutual solid solubility of silver and copper and the order-disorder transformation in the palladium-copper system, particularly the precipitation of the CuPd phase. In copper-free silver-palladium alloys, additions of indium or tin are necessary to provide hardenability which is achieved by the precipitation of tin- or indium-rich phases.

\section{Chemical Properties}

Materials which are used in the mouth, even temporarily, must be neither irritant nor damaging to the teeth or the tissues. Furthermore, they must be resistant to corrosion and tarnish in the oral environment. The slightest discolouration, although not affecting the value of the alloy from a functional point of view, is aesthetically unacceptable. Gold alloys which contain more than 50 atomic per cent of noble metals are not attacked by nitric acid (Tammann's rule) and are therefore considered resistant to chemical corrosion in the relatively milder mouth environment $(11,12)$. Figure 2 shows the region of chemical resistance of gold-silver-copper alloys and has been employed in drawing-up several specifications. According to the American Dental Association specification No. 5 of 1966, the international ISO 1562 of 1976 and the German DIN 13906 of 1975, dental casting gold alloys must contain a minimum of gold + PGM's of between 75 and 83 per cent by weight, depending on their class or 'Type' (Table II). No specification covers alloys containing less than 75 per cent noble metals or alloys intended for porcelain veneering. If it were possible to predict their corrosion and tarnish resistance in vivo by means of in vitro tests, the way would be open for specifications covering low gold content dental alloys in terms of this property as well as in terms of their composition. Although progress is being made in developing such tests, they cannot as yet be interpreted and relied upon with confidence.

\section{Physical Properties}

Specifications for dental casting gold alloys lay down requirements not only in respect of composition, but also in regard to physical properties. This is exemplified by ISO 1562 (Table II) which is applicable to a range of dental alloys extending from the very soft Type I alloys to the hardenable Type IV alloys. Apart from the hardness, minimum values are set for tensile strength, elongation to fracture and fusion temperature. The importance of minimum requirements for the mechanical properties of dental gold alloys arises from the large stresses to which a 
Table II

Requirements for Dental Casting Gold Alloys According to ISO 1562 of 1976

\begin{tabular}{|c|c|c|c|c|c|c|c|c|}
\hline Alloy & $\begin{array}{c}\text { Minimum Au + PGM's } \\
\text { content } \\
\text { wt. } \%\end{array}$ & $\begin{array}{l}\text { que } \\
\text { min. }\end{array}$ & $\begin{array}{l}\text { nell ha } \\
\text { numb } \\
\text { ed, } \\
\text { max. }\end{array}$ & $\begin{array}{l}\text { ness } \\
\text { hardened, } \\
\text { min. }\end{array}$ & $\begin{array}{c}\text { Minimum tensile } \\
\text { strength, } \\
\text { hardened, } \\
\mathrm{MPa}\end{array}$ & $\begin{array}{c}\text { Minimum } \\
\text { in } 50 \mathrm{~mm} \mathrm{~g} \\
\text { quenched, } \\
\%\end{array}$ & $\begin{array}{l}\text { elongation } \\
\text { auge length, } \\
\begin{array}{c}\text { hardened, } \\
\%\end{array}\end{array}$ & $\begin{array}{c}\text { Minimum fusion } \\
\text { temperature, } \\
{ }^{\circ} \mathrm{C}\end{array}$ \\
\hline $\begin{array}{l}\text { I } \\
\text { II } \\
\text { III } \\
\text { IV }\end{array}$ & $\begin{array}{l}83 \\
78 \\
78 \\
75\end{array}$ & $\begin{array}{r}40 \\
70 \\
90 \\
130\end{array}$ & $\begin{array}{r}75 \\
100 \\
140 \\
-\end{array}$ & $\begin{array}{l}- \\
\overline{2} \\
200\end{array}$ & $\begin{array}{l}- \\
- \\
620\end{array}$ & $\begin{array}{l}18 \\
12 \\
12 \\
10\end{array}$ & $\begin{array}{l}- \\
- \\
2\end{array}$ & $\begin{array}{l}930 \\
900 \\
900 \\
870\end{array}$ \\
\hline
\end{tabular}

restoration is exposed during mastication. For example, the stress at the tip of the root of a canine is about $100 \mathrm{MPa}$. In the area of the molars, mastication stresses are even higher and this has to be considered, particularly when designing long-span bridges.

The applications of gold alloys meeting ISO 1562 can range from fillings to crowns and bridges. Most of these alloys melt below $1000^{\circ} \mathrm{C}$ and are relatively easy to cast. However, gold alloys to which porcelain is fused must have a solidus temperature about $100^{\circ} \mathrm{C}$ higher than the firing temperature of dental porcelain which is between 960 and $980^{\circ} \mathrm{C}$. This is necessary to ensure that the castings do not sag during firing. It is essential for the integrity of the metal-porcelain bond that the coefficients of thermal expansion of both materials be compatible. Figure 3 shows the ranges of linear thermal expansion of typical dental gold alloys used for porcelain veneering along with those of the main dental porcelains. As porcelain can withstand compressive stresses better than tensile ones, it is desirable that the thermal expansion of the alloy should be a little above that of the porcelain. In this manner, compressive stresses are generated in the porcelain shell during cooling. Clearly, if the object of the intentional, slight difference between the thermal expansion of the metal and the porcelain is not to be defeated, the development of temperature gradients in the restoration must be avoided during its cooling from the firing temperature.

In addition to having precisely controlled physical properties, precious metal alloys for porcelain veneering must contain base metals capable of forming oxides which are necessary for the establishment of a strong porcelain-metal bond (14). These oxides form at the surface of the metal as it is heated and soaked during the firing cycle.

Exceptionally high demands are placed on the mechanical properties of gold alloys which are used

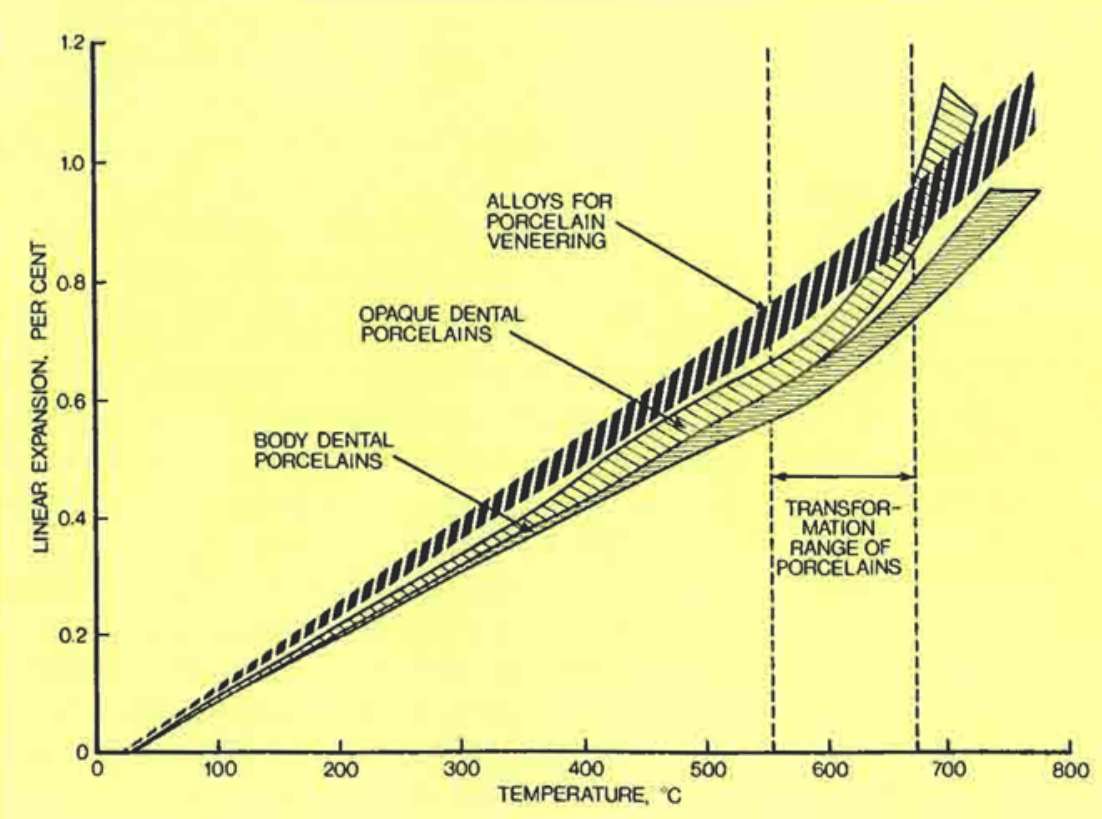

Fig. 3 Linear thermal expansion of dental opaque porcelains, body porcelains and dental alloys suitahle for porcelain veneering 
for partial dentures, clasps or orthodontic appliances. These alloys therefore have hardness values exceeding $300 \mathrm{H}_{v}$ and tensile strengths of more than $1000 \mathrm{MPa}$. Attachments also are made of high strength alloys. The required properties are without exception obtained by heat treatment of the finished prostheses. Sometimes the prostheses are cast onto pre-fabricated attachments made of a high melting range alloy which does not oxidize and is wetted by the casting alloy to ensure strong bonding.

If gold solders (because of their high melting ranges they are technically speaking brazes) are used, they must be similar in composition to the gold alloys of the parts to be joined (15). For gold alloys used in regular crown and bridge work, solders are available with working temperatures between 750 and $850^{\circ} \mathrm{C}$. When joining together alloys for porcelain veneering before the firing cycle, solders must be used with working temperatures that are well above the firing temperature. In practice, such solders melt between 1050 and $1150^{\circ} \mathrm{C}$. Modern gold solders are cadmium-free because of the toxic nature of cadmium oxide vapours.

\section{Applications of Dental Gold Alloys}

In the above, it was necessary to refer to specific applications of dental gold alloys as the requirements of these applications constitute the background against which metallurgists developed the current range of commercial products. In the sections which follow, a more detailed account is given of the numerous dental applications in which gold alloys have proved to be superior materials.

\section{Fillings}

In some countries, dentists still use the so-called direct filling golds for the plugging of cavities $(16,17)$. Direct filling gold is sold in the form of ribbons and rolls of pure gold foil. Sponge or matt gold is another direct filling material, supplied in the form of pellets or strips made by compressing and/or sintering very pure gold powder. Prior to use, both these forms of filling gold are heated for a few minutes over a flame in order to de-gas the surface of the metal. The gold, which is now in a more cohesive and easily bonded state, is then compacted into the cavity and hammered by hand or by mechanical means until the particles or foil surfaces cold-weld to one another. Besides being time consuming this technique is rather unpleasant for the patient.

An alternative method of filling a cavity is to cement into it a gold alloy inlay cast from an impression of the prepared cavity. Compared to other materials, such as amalgams, self-curing polymers and cements, Type I casting gold alloys (Table II) make the most durable fillings. Inlays made from these alloys are not hardenable, since if they were, their burnishing by the dentist after cementing into place would be difficult. ISO 1562 Type I alloys are usually gold-silver alloys (Table I).

\section{Crown and Bridge Work}

All types of fixed crowns and bridges can be made from gold-rich alloys of Types II, III and IV which are listed in Table II. These are alloys of the gold(-silver) (-copper)-PGM type, as shown in Table I.

Extra high strength Type IV alloys are used for removable dentures, long-span bridges, clasps, attachments and other fastening devices. However, low gold content alloys, based either on the goldpalladium or the silver-palladium systems, may also be used for all these applications.

The technique used to cast gold alloys into inlays, crowns and bridges is based on the lost wax process, which since its reintroduction at the turn of this century (1) has evolved into the precision investment
Fig. 4 A casting of a four-unit bridge, intended for veneering with a selfcuring resin, mounted on a plaster model of the patient's mouth

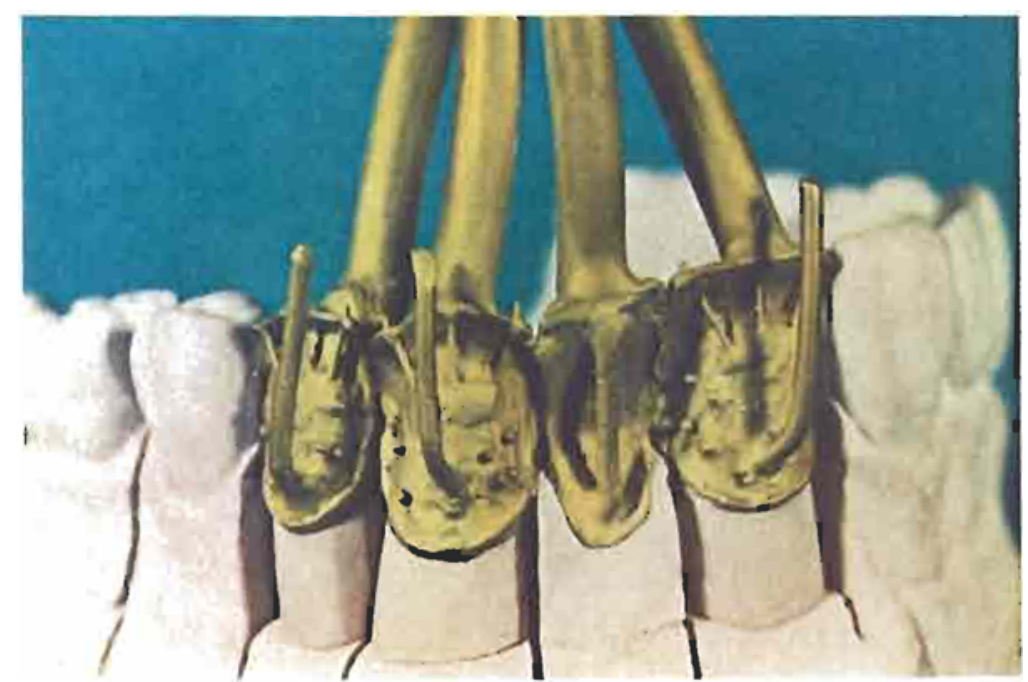




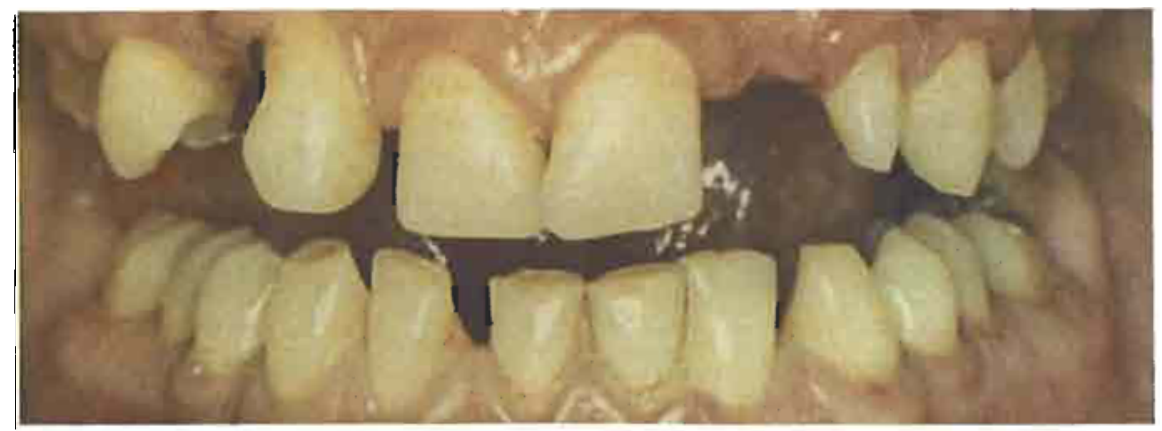

(a) The case before treatment

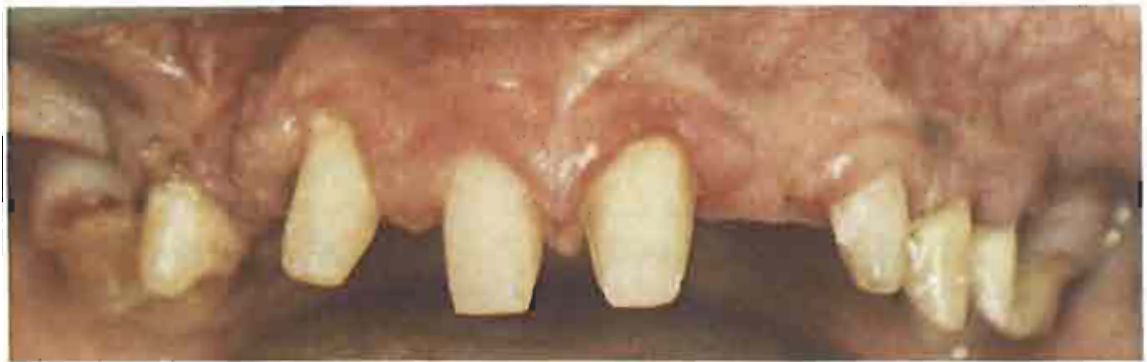

(b) Teeth of the upper jaw on completion of preparation work

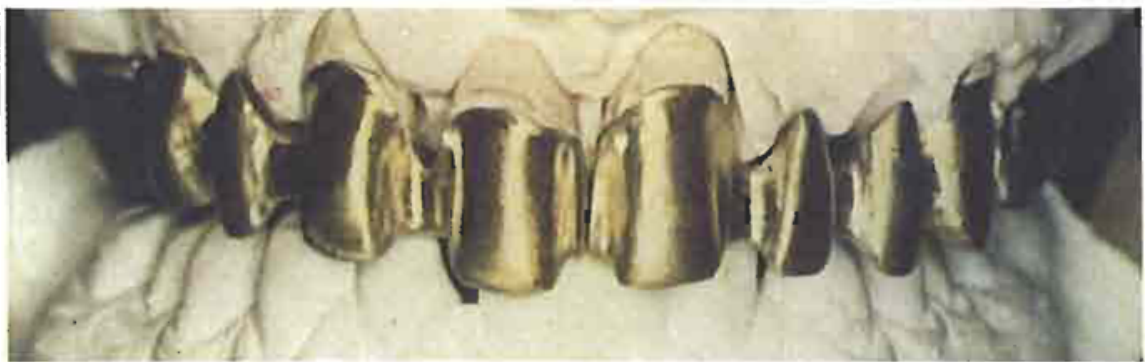

(c) Gold alloy framework on the plaster model of the patient's mouth

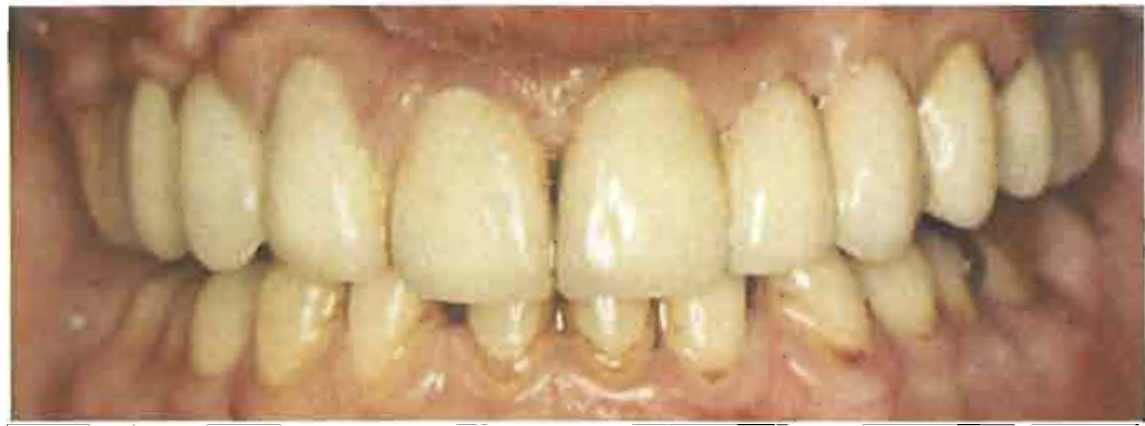

(d) Completed and fitted porcelain veneered bridge

Fig. 5 Four stages in the manufacture of a long span bridge made of gold alloy veneered with porcelain

casting process. The main reason for the universal adoption of this technique by modern dental laboratories is the need to produce castings which reproduce the wax pattern in every detail and dimension. The method consists of making a positive wax pattern from a negative impression of the patient's mouth, embedding this wax pattern into an investment slurry and, after setting, melting out the wax and then baking the mould. Gold alloys are easily melted in a resistance furnace or by means of a gas torch and are usually cast centrifugally.

After the liquid metal has entered the mould, its volume decreases as it solidifies and cools down to room temperature. The total contraction is the sum of that due to solidification of the melt and that of the casting as it cools from the solidus to room temperature. As in any other casting process, shrinkage during solidification must be compensated for by an adequate supply of molten metal. The contraction which takes place after the casting has solidified is to a large extent compensated for by the expansion of the investment which occurs during its setting and baking. This is the reason why dental investments, besides being capable of reproducing shape details accurately, must be carefully formulated to have a total expansion comparable to that of the 
alloy. Figure 4 shows a casting of a four-unit bridge mounted on a plaster model, with each unit having a sprue and a vent. It should be possible for the casting to fit in the mouth of the patient without difficulty, as it does on the plaster model. With gold alloys, the dimensional accuracy attained is about 0.1 per cent, which means that it is possible to achieve a total tolerance of a few hundredths of a millimetre on a large prosthesis.

\section{Porcelain Veneered Restorations}

The most recent development in restorative dentistry, which outstandingly satisfies technical as well as aesthetic requirements, is the fusion of a porcelain veneer to a metal substrate. The hardenable gold-rich light yellow or white alloys used for this purpose are based on the gold-platinum and the gold-platinumpalladium systems. Besides these, white gold alloys are also used which are based on the gold-palladium or palladium-silver systems (Table I). Porcelain veneers may be applied to restorations ranging from single crowns to complete bridges of fourteen units. Veneered prostheses combine the strength of the metal substrate with the durability and outstanding tissue tolerance of porcelain. Restorations made by this technique cannot be distinguished in appearance from natural teeth. Several decades of clinical experience, especially with gold-rich alloys, have not only led to technical perfection, but have brought about an excellent synthesis of function and aesthetics. Four stages in the manufacture of a porcelain-on-gold alloy bridge are shown in Figure 5. The missing teeth in the upper jaw are to be replaced by a thirteen-unit bridge. The metal framework shown in Figure $5 c$ endows the bridge with the requisite stability, while the natural colour of the translucent porcelain gives it a lifelike appearance, as illustrated in Figure 5d.

\section{Clasps and Attachments}

When a large number of teeth is missing and it is not possible to attach a bridge, then a partial denture is required which is primarily supported by the mucosa. However, in most cases, clasps around natural teeth are used to hold the denture in position. There are definite advantages in using gold alloys for making these clasps, since they should be stiff, tough and hardenable. Suitable formulations are of the gold(-silver)(-copper)-PGM type, which meet the above requirements (Table I).

Although clasps are very commonly fitted, they do not provide the best method of holding dentures in place, particularly when only a few natural teeth remain. Some even consider clasps as an effective means of extracting healthy teeth. It is possible to replace clasps by more suitable devices consisting of telescoping parts. The technique involves cementing primary crowns over the remaining natural teeth and then placing close-fitting, but removeable, secondary crowns, which are part of the prosthesis, over these primary crowns. There are several variations on this technique, and an example in the use of different attachments is shown in Figure 6.

\section{Pre-Fabricated Attachments}

It is possible to make high quality dental prostheses by using industrially pre-fabricated attachments. A few years ago the use of precision attachments was considered a sophisticated technique, but today it is common practice. There is available a variety of anchors, hinges, bar joints etc., which are mostly based on the male-female principle, to achieve fastening and accurate location of the prosthesis. High strength, hardenable precious metal alloys are used to manufacture precision attachments, and their main constituents are given in Table I. Some of these alloys are also used for pre-fabricated root canal posts which are devices used for fixing an artificial crown onto the remainder of a natural tooth.

\section{Orthodontic Appliances}

The appliances used in orthodontics are mostly made of nickel-chromium or cobalt-chromium alloys. An exception is the Crozat removable appliance, named after the American dentist George B. Crozat, which has once again found considerable application. The demands placed on orthodontic wires for Crozat appliances can be met only by alloys of precious metals, as Crozat himself fully realized. Since a Crozat appliance is made of wire only, it is comparatively comfortable to wear and inconspicuous. An additional advantage is that the forces exerted by these appliances on the teeth are finely adjustable. The technique is therefore equally effective on both adults and children (18). Silver-palladium-copper alloys containing small amounts of gold are the materials normally used for the manufacture of Crozat wires (see Table I).

\section{Solders}

Soldering is the process most extensively used in dental laboratories for joining two pieces of metal together. Alternative methods, for example casting one part onto another, are possible only with a few combinations of alloys. Laser and micro-plasma welding still remain at the development stage in spite of several years of investigation and it is unlikely that these techniques will be used in the near future in commercial dental laboratories (15).

As mentioned earlier, dental gold solders must be similar in composition to the parts which they are meant to join. Hence, each alloy group in Table I has 


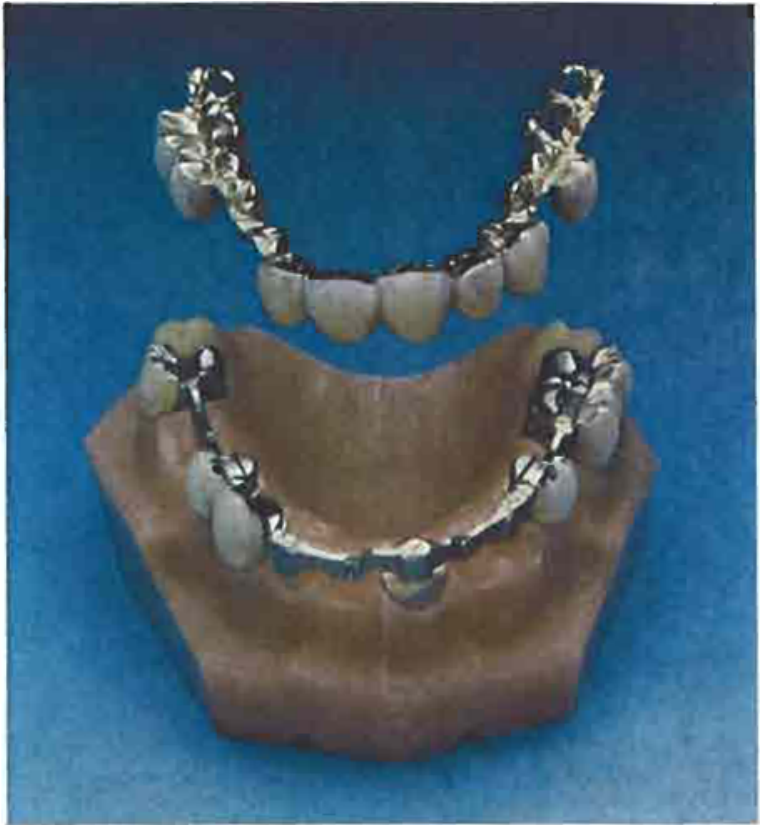

its own solders. Gold-nickel solders (Table I) are used for direct soldering of base metal alloys or steels and as an intermediary solder when these materials are joined to gold alloys.

An important condition for successful soldering is that the solder must readily wet the materials which it is supposed to join. This is made possible by the use of fluxes which dissolve surface oxides and form a cover, thereby preventing the formation of fresh oxides during the joining operation. Interdiffusion of the alloying components of the solder and the parent material takes place at the surface of contact. Although the diffusion zone remains very narrow, because of the short duration of the process, a strong bond is established. Propane or natural gas torches are normally used by dental technicians, but very fine solder work is carried out with a hydrogen- or propane-oxygen mixture. An additional technique is to solder in the conventional furnace which is used for baking the casting moulds.

\section{Implants}

Because of their extremely good corrosion resistance, some gold alloys are suitable as materials for dental implants. Successful animal experiments with blade-shaped, porcelain veneered gold-platinum alloy implants have been carried out (19). Histological examinations showed that new bone material had been formed, and inflammation, which normally occurs with metal implants, was absent. Another reason for using gold alloys for dental implants is that the post which protrudes from the gum has to be fitted with a crown. If dissimilar alloys are used for implant and crown, a galvanic cell may be created. In spite of
Fig. $6 \mathrm{~A}$ dental prosthesis of the attachment type on an anatomical model of the upper jaw. The precision interlocking devices fitted to the prosthesis and to the remaining teeth ensure more positive fastening than the commonly used clasps

several years of experience gained from animal and man, this field still remains outside of the scope of common dentistry.

\section{Concluding Remarks}

Tolerance by tissue, excellent corrosion and tarnish resistance, and good workability of the materials are the primary requirements for functional and aesthetically pleasing dental restorations. Noble metal alloys fulfil all these requirements. In view of this, price is of secondary importance. Furthermore, the cost of materials of most dental prostheses lies well below that of the labour involved in their manufacture. To date, no substitutes for dental gold alloys have emerged that can match them in their outstanding combinations of strength, workability and resistance to the oral environment. For this reason they remain, in many countries, the materials most extensively employed in prosthetic dentistry.

\section{References}

1 J. A. Donaldson, Gold Bull, 1980, 13, (3), $117-124$ and (4), 160-165

2 W. Hoffmann-Axthelm, 'Die Geschichte der Zahnheilkunde', Buch- und Zeitschriften-Verlag 'Die Quintessenz', Berlin, 1973

3 D. Potts, 'Gold 1980', Consolidated Gold Fields Limited, London, 1980

4. See, for example: American National Standards Institute/American Dental Association Specification No. 5 for Dental Casting Gold Alloys, in 'Guide to Dental Materials and Devices', 7th edition, American Dental Association, Chicago, IL., 1974, pp. 184-187

5 H. Knosp, Degussa-Brief, 1979, 45, 34-40

6 K. F. Leinfelder, W. J. O'Brien and D. F. Taylor, \%. Dent. Res., 1972, 51, 900-905

7 Y. Kanzawa, K. Yasuda and H. Metaki, J. Less-Common Met., $1975,43,121-128$

8 H. Knosp, Dental-Labor, 1978, 26, (1), 49-54

9 J. C. Chaston, Gold Bull., 1971, 4, (4), 70-71

10 G. Borelius, Phys. Scr., 1971, 4, 127-131

11 E. Wagner, 'Dentalchemie', in 'Ullmanns Encyklopädie der technischen Chemie', Vol. 10, 4th edition, 1975

12 M. Stümke, Degussa-Brief, 1979, 45, 3-14

13 G. Tammann, Z. Anorg. Allg. Chem., 1919, 107, 1-240

14 W. S. Rapson, Gold Bull., 1979, 12, (3), 108-114

15 H. Knosp, Quintessenz Zahntech., 1979, 5, (12), 73-78; 1980, 6, (1), 57-62 and (2), 63-69

16 R. G. Craig and F. A. Peyton, 'Restorative Dental Materials', The C.V. Mosby Co., Saint Louis, MO., 5th edition, 1975

17 R. W. Phillips, 'Science of Dental Materials', W.B. Saunders Co., Philadelphia, PA., 7th edition, 1973

18 H. Knosp, Disch. Zahnäratl. Z., 1977, 32, 373-377

19 H. G. Jacobs, 'Implantologie und Zahnersatz', Carl Hanser Verlag, München, 1976 